\title{
The contamination of Fabaceae plants with fungi and mycotoxins
}

\author{
Aleksandra S. Orina ${ }^{1}$, Olga P. Gavrilova ${ }^{1}$, Tatiana Yu. Gagkaeva ${ }^{1}$, Aleksey A. Burkin² and Galina P. Kononenko ${ }^{2}$ \\ ${ }^{1}$ Laboratory of Mycology and Phytopathology, All-Russian Institute of Plant Protection (VIZR), \\ 196608 St. Petersburg, Pushkin, Podbelskogo sh. 3, Russia \\ ${ }^{2}$ Mycotoxicology Laboratory, All-Russian Research Institute of Veterinary Sanitation, Hygiene, and Ecology - \\ Skryabin and Kovalenko Federal Scientific Center, All-Russian Research Institute of Experimental Veterinary Medicine, \\ 123022 Moscow, Zvenigorodskoe sh. 5, Russia \\ e-mail: t.gagkaeva@yahoo.com
}

\begin{abstract}
This study aimed to assess the contamination of Fabaceae plants with fungi and mycotoxins, which have a negative effect on the health of consumers of plant products. Quantitative PCR was used to analyse the DNA of Alternaria, Cladosporium and Fusarium fungi in 69 plant samples harvested from four Russian regions in 2015. Additionally, mycotoxins were analysed using ELISA. Cladosporium fungi DNA was found in all the analysed samples; the occurrence of Alternaria and Fusarium DNA was $84 \%$ and 51\%, respectively. Mycotoxin alternariol was detected in $100 \%$ and emodin in $90 \%$ of the samples. The occurrence of deoxynivalenol, diacetoxyscirpenol and T-2/HT-2 mycotoxins was $32 \%, 42 \%$ and $41 \%$, respectively. Plant species had no significant effect on the Alternaria, Cladosporium and Fusarium DNA content of the samples; however, the alternariol, emodin, deoxynivalenol and diacetoxyscirpenol contents differed significantly between plant species. The geographical origin had a statistically significant effect on the Alternaria and Fusarium DNA contents, likely due to differences in weather conditions.
\end{abstract}

Key words: legumes, Alternaria, Cladosporium, Fusarium, quantitative PCR, ELISA

\section{Introduction}

Forage legumes are characterised by high nutritive and protein-balanced values and are the main component of animal feed. They also ensure the preservation and maintenance of soil fertility. The cultivation of legumes is associated with a variety of factors that affect the quality of the final yield. One of these is the effect of fungal diseases, which are often characterised by high harmfulness (Tivoli et al. 1996, Allen and Lenné 1998).

According to many researchers, Alternaria Nees, Cladosporium Link and Fusarium Link fungi are the dominant group of mycobiota in forage legumes (Leach 1955, Lager and Johnsson 2002, Al-Askar et al. 2012, Kononenko et al. 2015). Most identified Alternaria and Cladosporium species are characterised as saprotrophic organisms, whereas many Fusarium species although being highly aggressive pathogens for legumes can also lead a saprotrophic life (Leach 1955, Kellock et al. 1978, Zaccardelli et al. 2006, Chittem et al. 2015, Gossen et al. 2016).

Analysis of the occurrence of isolated fungi revealed that Alternaria and Cladosporium fungi were the most abundant in the mycobiota of alfalfa seeds, with $100 \%$ prevalence; the average infection rate of these fungi was $10 \%$ and 22\%, respectively (Al-Askar et al. 2012).

Mycological analysis of the seed samples of four Trifolium species grown in the northwest of the USA found that Cladosporium cladosporioides (Fresen) G.A. de Vries significantly exceeded the occurrence of all other fungal species. This species was present in $11.5 \%$ of surface-sterilised seeds and almost $60 \%$ of untreated seeds. Alternaria fungi were the next most abundant (Leach 1955). Alternaria fungi prevailed in the microbiota of field peas in western Canada (Esmaeili Taheri et al. 2017).

Fusarium spp. appear to be quite common in Australia in Medicago plants, including, F. acuminatum Ellis et Everh., F. avenaceum (Fr.) Sacc., F. equiseti (Corda) Sacc., F. chlamydosporum Wollenw. \& Reinking, and F. graminearum Schwabe (Barbetti et al. 2006). The infection of legume seeds can also be associated with F. incarnatum (Desm.) Sacc., F. verticillioides (Sacc.) Nirenberg and F. solani (Mart.) Sacc. (Lamprecht et al. 1988, Zaccardelli et al. 2006, Al-Askar et al. 2012). Some of these species impede the germination of seedlings and the vigour of germinated seedlings. Fusarium fungi were the most frequently isolated pathogens from the roots of grain legumes in the USA and Canada (Chittem et al. 2015, Gossen et al. 2016). 


\section{AGRICULTURAL AND FOOD SCIENCE}

A.S. Orina et al. (2020) 29: 265-275

Forage plants contaminated with fungi often cause various allergies in farmers and animals (Lugauskas et al. 2004, Ajoudanifar et al. 2011, Żukiewicz-Sobczak et al. 2013). Spores of Cladosporium and Alternaria fungi have been shown to be present in significant amounts in the air and can cause severe allergic reactions leading to serious health problems (Hjelmroos 1993, Damialis et al. 2017). Quantitative PCR (qPCR), which reveals the biomass of fungi through the content of their DNA in plant tissues, was used in the current study, has been established as the most convenient method for the quick and objective assessment of infection levels in crops (Nicholson et al. 1998, Pavón et al. 2012, Kulik et al. 2015). This method was successfully applied for the detection and quantification of the DNA of seven Fusarium species associated with legumes (Zitnick-Anderson et al. 2018, Żelechowski et al. 2019). Some fungal species existent in plant mycobiota have the ability to produce mycotoxins, which have a negative effect on human and animal health (Barbetti and Allen 2005). Used as feed, forage legumes can also be a source of mycotoxins that affect the quality of agricultural products. The species-specific character of mycotoxin production is well known, but it is also affected by environmental factors (Schmidt-Heydt et al. 2009, 2011, Magan and Medina 2016). Previous studies have demonstrated the contamination of forage grasses with Alternaria and Fusarium mycotoxins (Tan et al. 2011, Nichea et al. 2015). An analysis of mycotoxins in legumes in Russia also revealed a high occurrence and accumulation of mycotoxin alternariol $(\mathrm{AOH})$ produced by Alternaria fungi, emodin (EMO) associated with Cladosporium fungi, and Fusarium mycotoxins (Gavrilova et al. 2017, Burkin and Kononenko 2018, Kononenko and Burkin 2018, 2019).

The aim of the current study was to assess the presence of Alternaria, Cladosporium and Fusarium fungi, and the mycotoxins they produce in the tissues of Fabaceae plants collected from various regions of European Russia in the context of plant traits.

\section{Materials and methods}

In total, 69 samples belonging to 12 plant species (Galega orientalis, Lathyrus pratensis, Medicago falcata, Medicago sativa, Melilotus albus, Melilotus officinalis, Trifolium hybridum, T. pratense, T. repens, Vicia cracca, V. sativa and $V$. sepium) of six genera from the Fabaceae family were collected from different regions of European Russia during the summer of 2015 (Table 1). Manuals were used to determine the plant species, life cycle, growth habit and melliferous capacity (Burmistrov and Nikitina 1990, Gubanov et al. 2003, Skvorcov 2004).

Table 1. Characteristics of the plant species used in this study

\begin{tabular}{|c|c|c|c|c|c|c|}
\hline Genus & Species & & $\begin{array}{l}\text { Number } \\
\text { of } \\
\text { samples }\end{array}$ & $\begin{array}{l}\text { Stem } \\
\text { growth }\end{array}$ & Life cycle & $\begin{array}{c}\text { Melliferous } \\
\text { capacity } \\
\left(\mathrm{kg} \mathrm{ha}^{-1}\right)\end{array}$ \\
\hline Lathyrus L. & L. pratensis L. & meadow vetchling & 6 & climbing & perennial & $-(30)$ \\
\hline Medicago L. & M. sativa $\mathrm{L}$. & alfalfa & 4 & erect & perennial & $+(170)$ \\
\hline \multirow[t]{2}{*}{ Melilotus Mill. } & M. albus Medik. & white sweet clover & 6 & erect & annual or biennial & $+(200)$ \\
\hline & M. officinalis (L.) Pall. & yellow sweet clover & 3 & erect & biennial & $+(200)$ \\
\hline Trifolium L. & T. hybridium L. & alsike clover & 9 & creeping & perennial & $+(145)$ \\
\hline \multirow{2}{*}{ Vicia $\mathrm{L}$. } & V. cracca L. & tufted vetch & 10 & $\begin{array}{l}\text { creeping / } \\
\text { climbing }\end{array}$ & perennial & $+(69)$ \\
\hline & V. sativa $\mathrm{L}$. & common vetch & 2 & erect & annual or biennial & $-(9)$ \\
\hline
\end{tabular}

Geographically, the analysed samples originated from Leningrad Oblast $(n=44)$, Novgorod Oblast $(n=5)$, Pskov Oblast $(n=11)$ and Smolensk Oblast $(n=9)$. These geographical areas are located throughout the north-western (Leningrad Oblast) and central European regions (Smolensk Oblast). 


\section{AGRICULTURAL AND FOOD SCIENCE}

The plant samples were collected in May and June $(n=26)$, in July $(n=20)$ and in August $(n=23)$. The weather conditions are presented in the Table 2.

Table 2. Weather conditions during 2015 in the sampled regions

\begin{tabular}{|c|c|c|c|c|c|c|}
\hline \multirow{2}{*}{$\begin{array}{l}\text { Region } \\
\text { (number of samples) }\end{array}$} & \multirow{2}{*}{ Month } & \multicolumn{3}{|c|}{ Month temperature, ${ }^{\circ} \mathrm{C}$} & \multirow{2}{*}{$\begin{array}{c}\text { Average } \\
\text { humidity, \% }\end{array}$} & \multirow{2}{*}{$\begin{array}{c}\text { Month rainfall, } \\
\mathrm{mm}\end{array}$} \\
\hline & & mean & $\min$ & $\max$ & & \\
\hline \multirow{2}{*}{ Leningrad Oblast $(n=44)$} & July & 16.9 & 7.9 & 25.1 & 73 & 86 \\
\hline & August & 18.2 & 9.1 & 28.2 & 68 & 47 \\
\hline \multirow{2}{*}{ Novgorod Oblast $(n=5)$} & July & 16.9 & 7.8 & 29.7 & 73 & 45 \\
\hline & August & 17.3 & 5 & 28.2 & 71 & 38 \\
\hline \multirow[t]{2}{*}{ Pskov Oblast $(n=11)$} & May-June & 16.7 & 4.4 & 27.5 & 93 & 90 \\
\hline & July & 18.2 & 4.2 & 29.2 & 72 & 94 \\
\hline \multirow{2}{*}{ Smolensk Oblast $(n=9)$} & July & 18.8 & 8.5 & 31.4 & 69 & 61 \\
\hline & August & 20.1 & 7.0 & 32.8 & 60 & 7 \\
\hline
\end{tabular}

Vegetative plants were cut at a height of $5 \mathrm{~cm}$ above the soil surface. The plants were dried at a temperature not higher than $50^{\circ} \mathrm{C}$. The dried plant samples were then separately homogenised in the sterilised grinding chambers of a batch mill (Tube Mill Control, IKA, Königswinter, Germany).

The total DNA from 200 mg of milled plant material was isolated using the Genomic DNA Purification Kit (Thermo Fisher Scientific, Vilnus, Lithuania) following the manufacturer's protocol. Using the same kit, DNA was also isolated from the mycelium of strains of F. graminearum MFG 58775, A. tenuissima MFP 556081 and Cladosporium sp. MFP 235011 cultivated on potato-sucrose agar. All the fungal strains were maintained in the collection of the Laboratory of Mycology and Phytopathology of the All-Russian Institute of Plant Protection, St. Petersburg, Russia. DNA concentrations from the samples and fungal strains were determined using a Qubit 2.0 fluorometer with a Quant-iT dsDNA HS Assay Kit (Thermo Fisher Scientific, Waltham, MA, USA) and aligned to 2-50 pg ng ${ }^{-1}$.

The DNA content of Alternaria, Cladosporium and the group of Fusarium fungi producing trichothecene mycotoxins (Tri-Fusarium) were evaluated using qPCR with TaqMan probes (Halstensen et al. 2006, Zeng et al. 2006, Yli-Mattila et al. 2008, Pavon et al. 2012). The reaction was carried out in a $20 \mu \mathrm{l}$ volume containing $10 \mu \mathrm{l}$ of a 2 $\times$ TaqAB master mix (AlkorBio, St. Petersburg, Russia), $300 \mathrm{nM}$ of each primer, $100 \mathrm{nM}$ of a fluorescent sample (Evrogen, Moscow, Russia) and $2 \mu$ of the DNA sample. All the qPCR assays were run using a thermocycler (CFX 96 Real-Time System; BioRad, Hercules, CA, USA), and the DNA content was presented as the ratio of fungal DNA to total DNA in each sample $\left(\mathrm{pg} \mathrm{ng}^{-1}\right)$. A low quantification limit of $5 \times 10^{-4} \mathrm{pg}$ fungal DNA on one ng of total DNA was established as the DNA threshold value for the samples; this could be quantitatively determined with high precision. All the samples were analysed at least twice.

For the mycotoxin detection, $1 \mathrm{~g}$ of milled plant material was placed in a tube containing $10 \mathrm{ml}$ of a mix of acetonitrile and water (84:16 v/v, respectively). The tube was shaken vigorously and left to incubate for $12-14 \mathrm{~h}$. After repeated shaking and 10-fold dilution with a buffer solution, the extract was used for an indirect competitive used enzyme-linked immunosorbent assay (ELISA). The determination of T-2/HT-2 toxins, deoxynivalenol (DON), diacetoxyscirpenol (DAS), $\mathrm{AOH}$ and EMO was performed using certified kits of immunoreagents and calibrants intended for the control of objects of plant origin (VNIIVSGE, Moscow, Russia). The lower limit of the quantitative measurements corresponded to an $85 \%$ level of antibody binding.

The data were analysed using Microsoft Office Excel 2010 (Microsoft, Redmond, WA, USA) and Statistica 10.0 (StatSoft, Tulsa, OK, USA). A standard t-test was used to determine statistically significant differences between the means. Relationships between the quantitative traits were evaluated using the linear Pearson correlation coefficient $(r)$. The results were considered significant when $p<0.05$. 


\section{AGRICULTURAL AND FOOD SCIENCE}

\section{Results}

The DNA of Alternaria fungi was detected in $84 \%$ of the samples. The maximum DNA content of these fungi was found in a Melilotus officinalis sample from Pskov Oblast: $3620 \times 10^{-4} \mathrm{pg} \mathrm{ng}^{-1}$. The average Alternaria DNA content in the analysed samples was $42 \times 10^{-4} \mathrm{pg} \mathrm{ng}^{-1}$. The DNA of Cladosporium fungi was found in $100 \%$ of the samples in the range of $7 \times 10^{-4}$ to $5490 \times 10^{-4} \mathrm{pg} \mathrm{ng}^{-1}$, with an average content of $586 \times 10^{-4} \mathrm{pg} \mathrm{ng}^{-1}$. The maximum Cladosporium DNA content was found in a sample of red clover from the Leningrad Oblast. The DNA of Tri-Fusarium fungi was detected in $51 \%$ of the samples in amounts of up to $492 \times 10^{-4} \mathrm{pg} \mathrm{ng}^{-1}$ (i.e. meadow vetchling from Smolensk Oblast).

Mycotoxin $\mathrm{AOH}$ was detected in $100 \%$ of the samples in amounts ranging from $20-1549 \mathrm{ppb}$, with an average content of $196 \mathrm{ppb}$. EMO was detected in $90 \%$ of the samples in amounts ranging from 17-10000 ppb, with an average content of $652 \mathrm{ppb}$. DON mycotoxin was detected in 32\% of the samples ranging from 100-631 ppb, DAS in $42 \%$ of the samples ranging from 141-1892 ppb and T-2/HT-2 toxins in $41 \%$ of the samples ranging from 4-27 ppb. The average contents of DON, DAS and T-2/HT-2 toxins were 221, 437 and 10 ppb, respectively.

\section{The effect of plant species}

The occurrence of Alternaria fungi varied widely among the sampled plant species and genera: from $33 \%$ in the bush vetch samples to $100 \%$ in the samples of common vetch, red clover, shamrock and sickle medick. On average, Melilotus plants accumulated the largest amount of Alternaria DNA compared to plants of other genera (Fig. 1). Plants from the Lathyrus and Trifolium genera were characterised by high levels of Cladosporium DNA compared to other legumes, whereas $G$. orientalis plants were the least contaminated by these fungi. The occurrence of TriFusarium varied from $25 \%$ in the Melilotus officinalis samples to $89 \%$ in the Trifolium hybridum samples, but the largest amounts of Tri-Fusarium DNA were detected in Lathyrus plants.

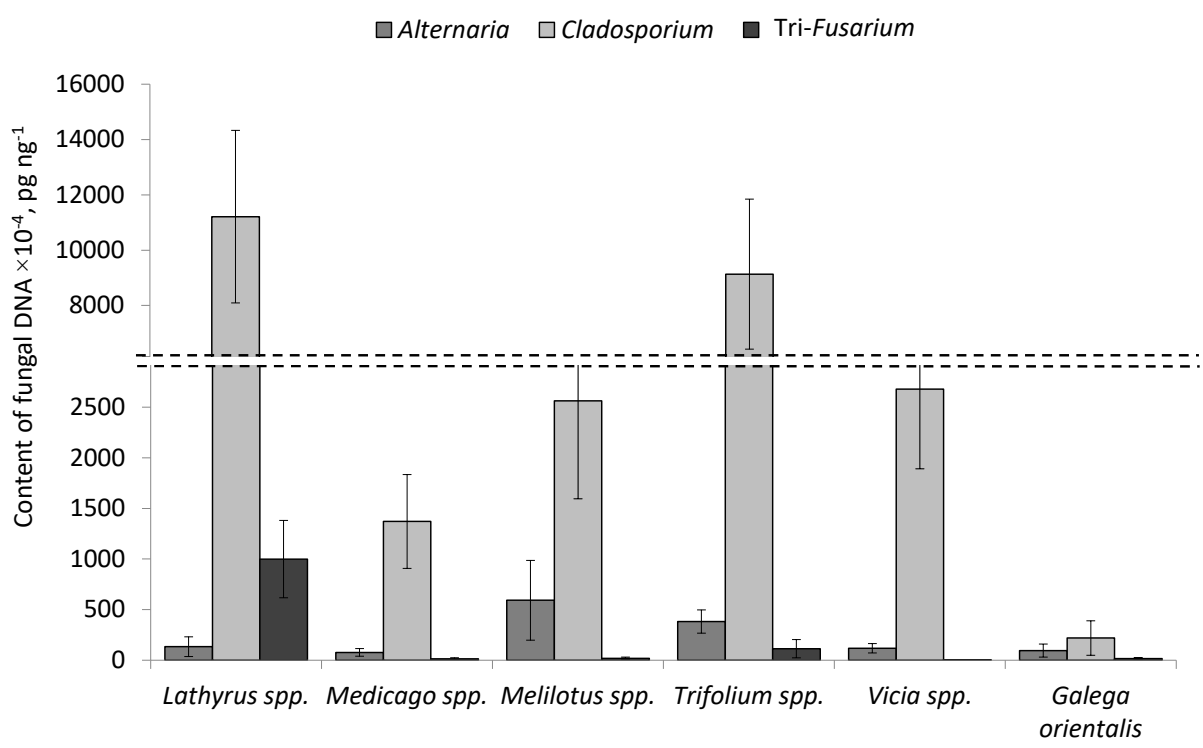

Fig. 1. Alternaria, Cladosporium and Tri-Fusarium DNA contents in samples of legume plants. The bars indicate confidence intervals with a 95\% significance level.

On average, the Lathyrus plant samples were the most contaminated by $\mathrm{AOH}(694 \pm 176 \mathrm{ppb})$, while Vicia and Melilotus plants were the least contaminated ( $53 \pm 9$ and $91 \pm 16 \mathrm{ppb}$, respectively). On average, samples of Trifolium plants ( $1284 \pm 402 \mathrm{ppb}$ ) were the most contaminated by EMO compared to the other legumes (from $19 \pm 11 \mathrm{ppb}$ in Melilotus plants to $257 \pm 86 \mathrm{ppb}$ in Lathyrus plants). Lathyrus plant samples were most contaminated by Fusarium mycotoxins (DON $=295 \pm 99 \mathrm{ppb}$, DAS $=879 \pm 279 \mathrm{ppb}$ and T-2/HT-2 toxins $=11 \pm 4 \mathrm{ppb}$ ), while none of the Fusarium mycotoxins were detected in the Vicia sepium samples.

An absence of a significant effect for plant species (12 species) on the amount of Alternaria, Cladosporium and Tri-Fusarium DNA in the samples was established. The effect of the genus (six genera) was substantial only for the amount of Tri-Fusarium DNA. The content of AOH, EMO, DON and DAS mycotoxins in the samples depended on 


\section{AGRICULTURAL AND FOOD SCIENCE}

A.S. Orina et al. (2020) 29: 265-275

the plant species. The effect of plant genus on the accumulation of mycotoxins also proved to be significant. However, the accumulation of T-2/HT-2 toxins was not dependent on either the plant species or genera.

\section{The effect of the geographical origin of the plant samples}

The average amounts of fungal DNA and mycotoxins differed in the legume samples depending on the region of origin (Table 3).

The occurrence of Alternaria fungi varied from 56\% (Smolensk Oblast) to 93\% (Leningrad Oblast), and Cladosporium fungi was detected in $100 \%$ of the examined samples. On average, the samples from Pskov Oblast were most infected by both these fungi. The occurrence of Tri-Fusarium fungi in the regions ranged from 45\% (Pskov Oblast) to $60 \%$ (Novgorod Oblast), but on average, the samples from Smolensk Oblast were 30-60 times more infected by these fungi. The geographical origins of the plant samples had a significant effect on the amount of Alternaria and Tri-Fusarium DNA, but an effect by this factor on Cladosporium infection was not seen.

$\mathrm{AOH}$ was found everywhere, whereas the occurrence of EMO in the samples varied from $60 \%$ (Novgorod Oblast) to $93 \%$ (Leningrad Oblast). DON was not detected in the samples from Novgorod Oblast; the highest frequency of this mycotoxin was found in the samples from Leningrad Oblast and Pskov Oblast (36\% each). The occurrence of DAS in the samples ranged from $27 \%$ to $48 \%$, and the occurrence of T-2/HT-2 toxins ranged from $18 \%$ to $56 \%$.

The maximum amounts of $\mathrm{AOH}, \mathrm{DON}, \mathrm{DAS}$ and T-2/HT-2 toxins were detected in the samples from Smolensk Oblast. The samples from Leningrad Oblast were more contaminated by EMO. The geographical origin of the plant samples had a substantial effect on the accumulation of DON and DAS, while the influence of this factor on the accumulation of the other mycotoxins was not statistically significant.

Table 3. Fungal DNA and mycotoxin contents in legume plants collected from different regions of Russia in 2015

\begin{tabular}{|c|c|c|c|c|c|c|c|c|}
\hline \multirow{2}{*}{$\begin{array}{l}\text { Geographical origin of } \\
\text { plant samples (number } \\
\text { of samples) }\end{array}$} & \multicolumn{3}{|c|}{$\begin{array}{l}\text { The average amount of fungal } \\
\text { DNA } \pm \mathrm{Cl} \times 10^{-4}, \mathrm{pg} \mathrm{ng}^{-1}\end{array}$} & \multicolumn{4}{|c|}{ The average amount of mycotoxins $\pm \mathrm{Cl}$, ppb } & \multirow[b]{2}{*}{$\begin{array}{c}\mathrm{T}-2 / \mathrm{HT}-2 \\
\text { toxins }\end{array}$} \\
\hline & Alternaria & Cladosporium & Tri-Fusarium & $\mathrm{AOH}$ & EMO & DON & DAS & \\
\hline Leningrad Oblast $(n=44)$ & $204 \pm 43$ & $4306 \pm 1356$ & $14 \pm 3$ & $182 \pm 26$ & $836 \pm 279$ & $63 \pm 14$ & $152 \pm 26$ & $5 \pm 1$ \\
\hline Novgorod Oblast $(n=5)$ & $176 \pm 65$ & $2707 \pm 445$ & $33 \pm 22$ & $58 \pm 12$ & $55 \pm 28$ & 0 & $60 \pm 36$ & $2 \pm 1$ \\
\hline Pskov Oblast ( $n=11)$ & $857 \pm 387$ & $10572 \pm 4741$ & $17 \pm 13$ & $192 \pm 79$ & $99 \pm 27$ & $55 \pm 25$ & $94 \pm 47$ & $1.4 \pm 0.7$ \\
\hline Smolensk Oblast $(n=9)$ & $62 \pm 33$ & $9466 \pm 3191$ & $965 \pm 567$ & $343 \pm 162$ & $252 \pm 73$ & $192 \pm 95$ & $564 \pm 267$ & $9 \pm 3$ \\
\hline
\end{tabular}

\section{The effect of the month of sample collection}

The distribution of samples contamination by fungi and mycotoxins was determined to depend on the month the plants were collected (Table 4).

The occurrence of Alternaria fungi increased from $85 \%$ in samples collected in May and June to $90 \%$ in samples collected in July, but it decreased to $78 \%$ in the August samples. Similarly, the occurrence of Tri-Fusarium fungi was $50 \%, 60 \%$ and $52 \%$, respectively. The occurrence of T-2/HT-2 toxins, DON and DAS mycotoxins increased at the end of the growing season. The proportion of samples in which at least one trichothecene mycotoxin was detected was $46 \%, 55 \%$ and $70 \%$ in May to June, July and August, respectively.

The total fungal DNA and all analysed mycotoxin contents in the forage legume samples increased during the growing season. An exception was the content of Alternaria DNA and EMO, which reached maximums in July. The effect of toxins by sampling month on the accumulation of metabolites in the samples was only significant for Alternaria and Cladosporium DNA and T-2/HT-2 toxins. 


\section{AGRICULTURAL AND FOOD SCIENCE}

A.S. Orina et al. (2020) 29: 265-275

Table 4. Alternaria, Cladosporium and Tri-Fusarium DNA and mycotoxins in samples of legume plants collected at different times during the 2015 growing period

\begin{tabular}{|c|c|c|c|c|c|c|c|c|}
\hline \multirow{2}{*}{$\begin{array}{l}\text { The month } \\
\text { (number of } \\
\text { samples) }\end{array}$} & \multicolumn{3}{|c|}{$\begin{array}{l}\text { The average amount of fungal } \\
\text { DNA } \pm \mathrm{Cl} \times 10^{-4}, \mathrm{pg} \mathrm{ng}^{-1}\end{array}$} & \multicolumn{5}{|c|}{ The average amount of mycotoxins $\pm \mathrm{Cl}, \mathrm{ppb}$} \\
\hline & Alternaria & Cladosporium & Tri-Fusarium & $\mathrm{AOH}$ & EMO & DON & DAS & $\begin{array}{l}\mathrm{T}-2 / \mathrm{HT}-2 \\
\text { toxins }\end{array}$ \\
\hline May-June $(n=26)$ & $164 \pm 51$ & $285 \pm 54$ & $18 \pm 6$ & $156 \pm 28$ & $580 \pm 254$ & $53 \pm 15$ & $111 \pm 30$ & $1.5 \pm 0.5$ \\
\hline July $(n=20)$ & $585 \pm 224$ & $8133 \pm 2680$ & $17 \pm 7$ & $199 \pm 52$ & $118 \pm 24$ & $40 \pm 15$ & $136 \pm 41$ & $3 \pm 1$ \\
\hline August ( $n=23)$ & $169 \pm 46$ & $10192 \pm 2714$ & $385 \pm 235$ & $239 \pm 71$ & $999 \pm 448$ & $126 \pm 42$ & $325 \pm 111$ & $8 \pm 2$ \\
\hline
\end{tabular}

\section{The effect of plant habit}

Sampled plants with erect stems (V. sativa, Melilotus spp., G. orientalis and Medicago spp.) had a lower occurrence of Alternaria (71\%) and Tri-Fusarium (42\%) fungi than the samples of plants with creeping stems (Lathyrus spp., Trifolium spp., V. sepium and V. cracca): $91 \%$ and $60 \%$, respectively.

On average, the Alternaria and Tri-Fusarium DNA contents did not differ significantly for plant samples with erect or creeping stems (Fig. 2). However, a significant effect of stem growth on infection with Cladosporium fungi was revealed. On average, plants with creeping stems accumulated the DNA of these fungi 4.5 times more than plants with erect stems.

The occurrence of trichothecene mycotoxins in the erect-stem plant samples was $2.5-5$ times lower than in the creeping-stem plant samples. The proportions of plant samples with erect and creeping stems, in which at least one trichothecene mycotoxin was found, were $28 \%$ and $70 \%$, respectively. Plants with erect stems were significantly less contaminated by all the analysed mycotoxins. The most substantial difference was for EMO; its content in creeping plants was 17 times higher than in erect plants. The $\mathrm{AOH}$ and trichothecene mycotoxin contamination of the creeping plants was 2.5-6 times more than that of the erect plants. Plant habit had a significant effect on the accumulation of all the analysed mycotoxins.

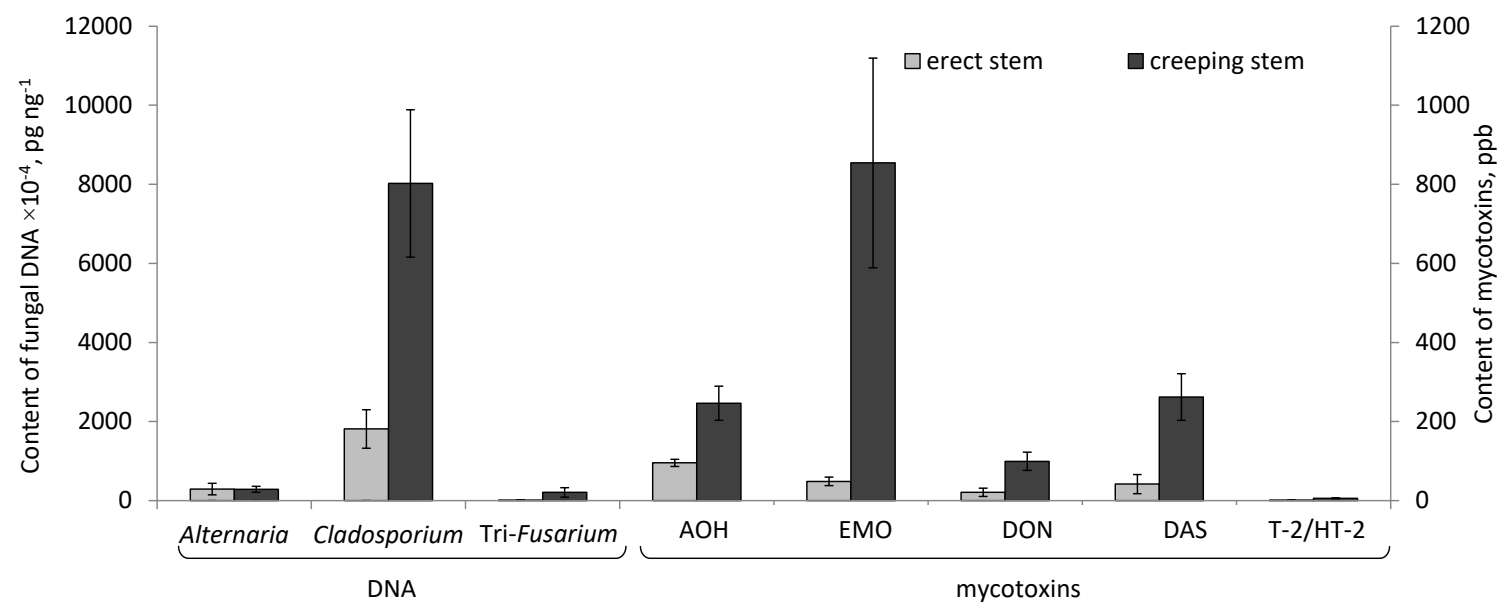

Fig. 2. Fungal DNA and mycotoxins contents in legume plant samples with different stem growths. The bars indicate confidence intervals with a $95 \%$ significance level.

\section{The effects of life cycle and melliferous capacity}

The occurrence of Alternaria fungi in the annual/biennial legume (Melilotus spp. and $V$. sativa) and perennial legume plant samples (G. orientalis, Lathyrus spp., Medicago spp., Trifolium spp., V. sepium and V. cracca) was $73 \%$ and $88 \%$, respectively. At the same time, the perennial legume samples were 2 times less contaminated with Alternaria fungi compared to the annual/biennial plants. Cladosporium fungi were found in $100 \%$ of the samples, but no significant effect of life cycle on the accumulation of Cladosporium DNA was found. The occurrence of TriFusarium fungi did not depend on life cycle either; they were detected in half of the samples in each group: 55\% and $53 \%$, respectively. However, perennial legume plants contained an average of 10 times more Tri-Fusarium DNA than the annual/biennial plants (Fig. 3A). 


\section{AGRICULTURAL AND FOOD SCIENCE}
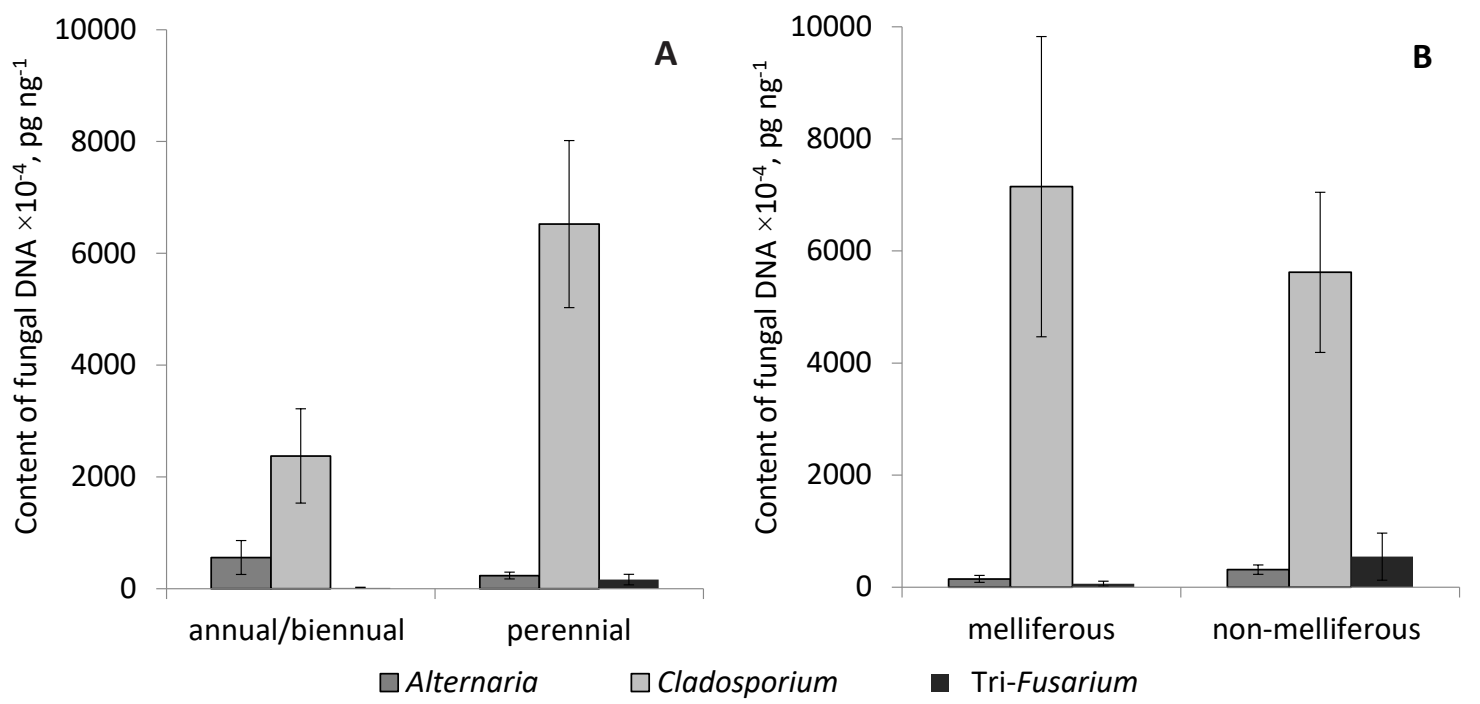

Fig. 3. Fungal DNA content in legume plant samples with different (A) life cycles and (B) melliferous capacity. The bars indicate confidence intervals with a $95 \%$ significance level.

The occurrence of all analysed mycotoxins in the annual/biennial plant samples was 2-6 times less than in the perennial grasses. The perennial legumes also contained more of all the analysed mycotoxins compared to the annual/biennial plants, but this difference was not statistically significant for any of the mycotoxins.

On average, the occurrence of Alternaria and Tri-Fusarium fungi in melliferous legume plants was higher $(90 \%$ and $57 \%$, respectively) than in non-melliferous legumes ( $64 \%$ and $36 \%$, respectively), while Cladosporium fungi were found in $100 \%$ of the samples.

The contamination of melliferous and non-melliferous legumes with Alternaria and Cladosporium fungi was not significantly different (Fig. 3B). Non-melliferous plants were 12 times more contaminated with Tri-Fusarium fungi than melliferous plants, and this difference was significant.

The occurrence of $\mathrm{AOH}$ and $\mathrm{EMO}$ mycotoxins in the samples of melliferous and non-melliferous legumes was approximately the same, ranging from $88 \%$ to $100 \%$. The occurrence of trichothecene mycotoxins in the non-melliferous legumes was in the range of $28 \%-40 \%$, which was less than the similar values for melliferous plants, in which the occurrence of these mycotoxins was 55\%-64\%. The contamination of non-melliferous legumes by $\mathrm{AOH}$, DON and DAS trichothecene mycotoxins was 1.5-5 times higher than for melliferous plants and the difference was significant. The opposite tendency was observed for EMO: this toxin accumulated in non-melliferous legumes 4.5 times less than in melliferous ones, but it was not statistically significant.

\section{Discussion}

Differences in the habits and life cycles of legumes complicate the correct analysis of their microbiological contamination. The facility of molecular methods, whereby DNA is extracted in the first stage from an average homogeneous sample obtained by grinding whole plants, represents great advantages compared with traditional methods. The active application of molecular methods to assess the microbiological status of plants has been observed in recent years (Kulik et al. 2015, Gagkaeva et al. 2017, Zitnick-Anderson et al. 2018).

In the mycobiota of forage legumes, Alternaria, Cladosporium and Fusarium fungi have been found to be the dominant group (Leach 1955, Lager and Johnsson 2002, Al-Askar et al. 2012, Kononenko et al. 2015). In our study, Cladosporium fungi were also the most common among the three analysed groups of fungi, and they were found in all the samples. The most favourable substrates for these fungi were Lathyrus and Trifolium plants, in which a high content of Cladosporium DNA was found. The DNA content of these fungi in the group of plants with creeping stems was significantly higher than in plants with erect stems. According to Tivoli et al. (1996), as a result of higher humidity at the base of the pea canopy, greater development of leaf blight is observed in the lower part of pea plants. In support of this, accessions of Trifolium pratense with erect growth habit were less susceptible to rot compared with creeping forms of red clover (Vleugels et al. 2013). 


\section{AGRICULTURAL AND FOOD SCIENCE}

A.S. Orina et al. (2020) 29: 265-275

In the spring samples, the content of Cladosporium DNA was significantly lower compared with the plants collected later in the year. The colonisation of pea (Pisum sativum) leaves by fungi has been previously described; an increase of predominant Cladosporium spp. by the end of the growing season has been observed (Dix and Webster 1995). Probably, the dramatic prevalence of Cladosporium conidia in the air compared to the number of other fungal conidia (Grinn-Gofron et al. 2016) is associated with the significant contamination of plants by these fungi.

On average, the highest amount of Alternaria DNA was found in the Melilotus plants. The geographical origin and the month sampled had a statistically significant effect on the content of Alternaria DNA, while the effects of plant species, genus and traits were accidental. Therefore, environmental conditions had the greatest effect on the distribution of these fungi. The contamination of legume plants by Alternaria fungi reached a maximum in July compared with samples collected earlier and later. According to available weather conditions in the analysed regions, July 2015 was characterised by the highest rainfall in most areas. The correlation between rainfall and Alternaria DNA content was significant $(r=+0.28)$, while the average temperature and humidity were not substantial. Differences in the Alternaria DNA content between the regions were congruent: samples from the Pskov Oblast with the highest rainfall were the most infected, while samples from the Smolensk Oblast with the minimum rainfall were the least infected. It is known that the penetration and growth of fungi in plant tissues are affected by environmental conditions, but according to some researchers, the effect of rainfall during the growing season has a more significant effect on the development of Alternaria leaf blight than temperature (Saharan and Saharan 2004, Meno et al. 2019).

Tri-Fusarium fungi producing trichothecene mycotoxins were found in half of the analysed legume samples. On average, a significantly higher content of their DNA was found in the Lathyrus plants. The geographical origin of the samples had a statistically significant effect on the content of Tri-Fusarium DNA, while the effects of sampling month, plant species, genus and traits were accidental. In the plant samples from the Smolensk Oblast, the average content of Tri-Fusarium fungi was higher than in samples from other regions. The weather conditions in this region were characterised by the highest average temperature for all the summer months during 2015 compared with the other analysed regions. The correlation between the average monthly temperature and the Tri-Fusarium DNA content was significant $(r=+0.29)$.

Analysis of the relationships between the analysed fungi revealed a significant positive correlation between the Alternaria and Cladosporium fungi DNA contents in the plant samples ( $r=+0.37)$. In the samples collected in July and August, this connection was more substantial ( $r=+0.46$ and +0.56 , respectively). When analysing the fungi contamination of samples grouped according to traits, this connection was even more significant: in plants with creeping stems, the correlation coefficient between the Alternaria and Cladosporium fungi DNA contents was $r=+0.47$, and in the annual/biennial plant samples, its value reached $r=+0.50$. This demonstrates the similarity of the conditions required for the growth of Alternaria and Cladosporium fungi, especially in conditions favourable for saprotrophic fungi (i.e. proximity of the soil and aging plant tissue). Previous molecular analyses have revealed a similarly significant relationship between Alternaria and Cladosporium fungi coexisting in small grain cereals (Kulik et al. 2015, Gagkaeva et al. 2017) and legumes (Orina et al. 2018).

Our study did not reveal any significant effect of sampling month on the accumulation of mycotoxins in legumes tissues. A tendency for mycotoxin accumulation over the growing season was not found in T. pratense, Medicago spp. or Melilotus spp. plants collected from other regions of Russia (Burkin and Kononenko 2018, Kononenko and Burkin 2018). In addition, there were no differences in the content of Fusarium mycotoxins in naturally growing herbs from the Poaceae family collected in spring and summer in one region of Argentina (Nichea et al. 2015). However, the EMO, AOH, DON and DAS contents in samples of Lathyrus pratensis collected in August were significantly higher than in plant samples collected in May and June (Kononenko and Burkin 2019).

No statistically significant effect of life cycle on the amount of fungal DNA or mycotoxin content was detected, although, according to our results, the perennial legumes contained more of all the analysed mycotoxins compared with the annual/biennial plants. This is consistent with Engels and Krämer (1996), who found high T-2 toxin, ZEA and, especially, DAS content in perennial ryegrass compared with annual ryegrass.

According to our results, the content of Alternaria and Cladosporium DNA in melliferous and non-melliferous legumes was not significantly different. The opposite situation was found in the case of the Tri-Fusarium fungi: non-melliferous legumes were contaminated with significantly higher amounts of Tri-Fusarium DNA than melliferous ones, as well as with DON and DAS mycotoxins. According to some researchers, flowering plant pollen can stimulate conidia germination and the growth of fungi on leaf surfaces by reducing nutritional competition. 


\section{AGRICULTURAL AND FOOD SCIENCE}

A.S. Orina et al. (2020) 29: 265-275

The abundance of pollen in the atmosphere coincides with an increase in the numbers of Alternaria and Cladosporium conidia during the summer months, and pollen and spores are deposited together on plant surfaces in great numbers (Dix and Webster 1995). Bees can also contribute to plant infection by transferring fungal conidia. Analyses of bee pollen have revealed the ubiquitous presence and predominance of Alternaria, Mucor, AspergilIus and Cladosporium fungi, and Aureobasidium and Penicillium have also often been found, whereas Fusarium fungi have not been detected (Osintseva and Chekryga 2008, Kačániová et al. 2011, Deveza et al. 2015).

A correlation between the content of Alternaria DNA and mycotoxin AOH in all the analysed legume samples was not detectable. This was probably because the current study analysed the presence of these fungi at the genus level, while different Alternaria species are characterised by a contrasting ability to produce this mycotoxin (Andersen et al. 2002). Additionally, the correlation between the Cladosporium DNA and mycotoxin EMO contents was significant ( $r=+0.38$ ). Various fungi can produce EMO (Kusari et al. 2008), and this is also a known metabolite of some plants (Izhaki 2002). Cladosporium fungi are probably not the exclusive producers of this mycotoxin in legume tissues; however, the contribution of these fungi is substantial. A correlation was established between the Tri-Fusarium DNA and DON and DAS mycotoxins contents ( $r=+0.39$ for each) observed in the group of creepingstem plants ( $r=+0.31$ and +0.33 , respectively) and perennial plant samples $(r=+0.34$ and +0.36 , respectively). The correlation between the trichothecene mycotoxin contents was also significant (T-2/HT-2 toxins and DON=+0.48, $\mathrm{T}-2 / \mathrm{HT}-2$ toxins and DAS $=+0.52$, and $\mathrm{DON}$ and $\mathrm{DAS}=+0.85)$.

The current study's findings on the distribution of fungi and their relationships with host plants and each other are of high scientific and practical interest. Knowledge about the contamination of legumes with fungi and mycotoxins is important for human and animal health. It is obligatory to use fast, highly sensitive methods for the detection of fungi and their metabolites in plants to reliably predict possible dangers to consumers.

\section{Acknowledgements}

The analysis of experimental data was carried out with support from the Russian Science Foundation (project 1976-30005).

\section{References}

Ajoudanifar, H., Hedayati, M.T., Mayahi, S., Khosravi, A. \& Mousavi, B. 2011. Volumetric assessment of airborne indoor and outdoor fungi at poultry and cattle houses in the Mazandaran Province, Iran. Arhiv za Higijenu Rada i Toksikologiju 62: $243-248$. https://doi.org/10.2478/10004-1254-62-2011-2099

Al-Askar, A.A., Ghoneem, K.M. \& Rashad, Y.M. 2012. Management of some seed-borne pathogens attacking alfalfa plants in Saudi Arabia. African Journal of Microbiology Research 7: 1197-1206. https://doi.org/10.5897/AJMR12.739

Allen, D.J. \& Lenn'e, J.M. 1998. The pathology of food and pasture legumes. Wallingford, Oxon, UK: CAB International. 750 p.

Andersen, B., Krøger, E. \& Roberts, R.G. 2002. Chemical and morphological segregation of Alternaria arborescens, A. infectoria and A. tenuissima species-group. Mycological Research 106: 170-182. https://doi.org/10.1017/S0953756201005263

Barbetti, M.J. \& Allen, J.G. 2005. Association of Fusarium species, with potential for mycotoxicosis, on pods of annual Medicago in Western Australia. Australian Journal of Agricultural Research 56: 279-284. https://doi.org/10.1071/AR04172

Barbetti, M.J., Riley, I.T., You, M.P, Li, H. \& Sivasithamparam, K. 2006. The association of necrotrophic fungal pathogens and plant parasitic nematodes with the loss of productivity of annual medic-based pastures in Australia and options for their management. Australasian Plant Pathology 35: 691-706. https://doi.org/10.1071/AP06075

Burkin, A.A. \& Kononenko, G.P. 2018. Secondary metabolites of micromycetes in plants of the family Fabaceae genera Galega, Glycyrrhiza, Lupinus, Medicago, and Melilotus. Biology Bulletin 45: 235-241. https://doi.org/10.1134/S1062359018030020

Burmistrov, A.N. \& Nikitina, V.A. 1990. Honey plants and their pollen: Directory. Moscow, Russia: Rosagropromizdat. 192 p. (in Russian).

Chittem, K., Mathew, F.M., Gregoire, M., Lamppa, R.S., Chang, Y.W., Markell, S.G., Bradley, C.A., Barasubiye, T. \& Goswami, R.S. 2015. Identification and characterization of Fusarium spp. associated with root rots of field pea in North Dakota. European Journal of Plant Pathology. 143: 641-649. https://doi.org/10.1007/s10658-015-0714-8

Damialis, A., Kaimakamis, E., Konoglou, M., Akritidis, I., Traidl-Hoffmann, C. \& Gioulekas, D. 2017. Estimating the abundance of airborne pollen and fungal spores at variable elevations using an aircraft: how high can they fly? Scientific Reports 7: 44535. https://doi.org/10.1038/srep44535

Deveza, M.V., Keller, K.M., Lorenzon, M.C.A., Nunes, L.M.T., Sales, É.O. \& Barth O.M. 2015. Mycotoxicological and palynological profiles of commercial brands of dried bee pollen. Brazilian Journal of Microbiology 46: 1171-1176. https://doi.org/10.1590/S1517-838246420140316

Dix, N.J. \& Webster, J. 1995. Colonization and decomposition of leaves. In: Dix, N.J. \& Webster, J. (eds.). Fungal Ecology. Dordrecht, Netherlands: Springer. p. 85-127. https://doi.org/10.1007/978-94-011-0693-1_4 
Engels, R. \& Krämer, J. 1996. Incidence of Fusaria and occurrence of selected Fusarium mycotoxins on Lolium spp. in Germany. Mycotoxin Research 12: 31-40. https://doi.org/10.1007/BF03192078

Esmaeili Taheri, A., Chatterton, S., Foroud, N.A., Gossen, B.D. \& McLaren, D.L. 2017. Identification and community dynamics of fungi associated with root, crown, and foot rot of field pea in western Canada. European Journal of Plant Pathology 147: 489-500. https://doi.org/10.1007/s10658-016-1017-4

Gavrilova, O.P., Orina, A.S. \& Gagkaeva, T.Yu. 2017. Quantitative assessment of fungal infection in Trifolium species and mycotoxins contamination. Agrochemistry 11: 58-66. (in Russian). https://doi.org/10.7868/S0002188117110072

Gagkaeva, T., Gavrilova, O.P., Orina, A.S., Blinova, E.V. \& Loskutov, I.G. 2017. Response of wild Avena species to fungal infection of grain. The Crop Journal 5: 499-508. https://doi.org/10.1016/j.cj.2017.04.005

Gossen, B., Conner, R., Chang, K., Pasche, J., McLaren, D., Henriquez, M., Chatterton, S. \& Hwang, S. 2016. Identifying and managing root rot of pulses on the Northern Great Plains. Plant Disease 100: 1965-1978. https://doi.org/10.1094/PDIS-02-16-0184-FE

Grinn-Gofroń, A., Strzelczak, A., Stępalska, D. \& Myszkowska, D. 2016. A 10-year study of Alternaria and Cladosporium in two Polish cities (Szczecin and Cracow) and relationship with the meteorological parameters. Aerobiologia 32: 83-94. https://doi.org/10.1007/s10453-015-9411-5

Gubanov, I.A., Kiseleva, K.V., Novikov, V.S. \& Tihomirov, V.N. 2003. Illustrated manual of plants in Central Russia. V. 2. Magnoliophyta (dicotyledon: dialypetalous). Moscow, Russia: KMK, Institut tekhnologicheskih issledovanij. 665 p. (in Russian).

Halstensen, A.S., Nordby, K.C., Eduard, W. \& Klemsdal, S.S. 2006. Real-time PCR detection of toxigenic Fusarium in airborne and settled grain dust and associations with trichothecene mycotoxins. Journal of Environmental Monitoring 8: 1235-1241. https://doi.org/10.1039/b609840a

Hjelmroos, M. 1993. Relationship between airborne fungal spore presence and weather variables: Cladosporium and Alternaria. Grana 32: 40-47. https://doi.org/10.1080/00173139309436418

Izhaki, I. 2002. Emodin - A secondary metabolite with multiple ecological functions in higher plants. New Phytologist 155: 205217 https://doi.org/10.1046/j.1469-8137.2002.00459.x

Kačániová, M., Juráček, M., Chlebo, R., Kňazovická, V., Kadasi-Horáková, M., Kunová, S., Lejková, J., Haščík, P., Mareček, J. \& Šimko , M. 2011. Mycobiota and mycotoxins in bee pollen collected from different areas of Slovakia. Journal of Environmental Science and Health. 46: 623-629. https://doi.org/10.1080/03601234.2011.589322

Kellock, A.W., Stubbs, L.L. \& Parbery, D.G. 1978. Seed-borne Fusarium species on subterranean clover and other pasture legumes. Australian Journal of Agricultural Research 29: 975-982. https://doi.org/10.1071/AR9780975

Kononenko, G.P. \& Burkin, A.A. 2018. Secondary metabolites of micromycetes in plants of the family Fabaceae, genus Trifolium. Biology Bulletin 45: 132-138. https://doi.org/10.1134/S1062359018020048

Kononenko, G.P. \& Burkin, A.A. 2019. Secondary metabolites of micromycetes in plants of the family Fabaceae, genera Lathyrus, Vicia. Biology Bulletin 46: 219-224. https://doi.org/10.1134/S106235901903004X

Kononenko, G.P., Burkin, A.A., Gavrilova, O.P. \& Gagkaeva, T. 2015. Fungal species and multiple mycotoxin contamination of cultivated forage grasses. Agricultural and Food Science 24: 323-330. https://doi.org/10.23986/afsci.52313

Kulik, T., Treder, K. \& Załuski, D. 2015. Quantification of Alternaria, Cladosporium, Fusarium and Penicillium verrucosum in conventional and organic grains by qPCR. Journal of Phytopathology 163: 522-528. https://doi.org/10.1111/jph.12348

Kusari, S. \& Spiteller, M. 2012. Metabolomics of endophytic fungi producing associated plant secondary metabolites: progress, challenges and opportunities. In: Roessner U. (ed.) Metabolomics. London: InTech. p. 241-266.

Lager, J. \& Johnsson, L. 2002. Seed-borne fungi affect field emergence in red clover. Journal of Plant Diseases and Protection 109: 350-356.

Lamprecht, S.C., Knox-Davies, P.S. \& Marasas, W.F.O. 1988. Fungi associated with root rot of annual Medicago spp. in South Africa. Phytophylactica 20: 281-286.

Leach, C.M. 1955. Fungi associated with Oregon grown clover seed. Corvallis: Oregon state college. 141 p.

Lugauskas, A., Krikstaponis, A. \& Sveistyte, L. 2004. Airborne fungi in industrial environments - potential agents of respiratory diseases. Annals of Agricultural and Environmental Medicine 11: 19-25.

Magan, N. \& Medina, A. 2016. Integrating gene expression, ecology and mycotoxin production by Fusarium and Aspergillus species in relation to interacting environmental factors. World Mycotoxin Journal 9: 673-684. https://doi.org/10.3920/WMJ2016.2076

Meno, L., Escuredo, O., Rodríguez-Flores, M.S. \& Seijo, M.C. 2019. Interrupted wet period (IWP) to forecast the aerial Alternaria in potato crops of a Limia (Spain). Agronomy 9: 585. https://doi.org/10.3390/agronomy9100585

Nichea, M., Palacios, S., Chiacchiera, S.M., Sulyok, M., Krska, R., Chulze, S. \& Ramirez, M. 2015. Presence of multiple mycotoxins and other fungal metabolites in native grasses from a wetland ecosystem in Argentina intended for grazing cattle. Toxins 7 : 3309-3329. https://doi.org/10.3390/toxins7083309

Nicholson, P., Simpson, D.R., Weston, G., Rezanoon, H.N., Less, A.K., Parry, D.W. \& Joyce, D. 1998. Detection and quantification of Fusarium culmorum and Fusarium graminearum in cereals using PCR assays. Physiological and Molecular Plant Pathology 53: 17-37. https://doi.org/10.1006/pmpp.1998.0170

Orina, A.S., Gavrilova, O.P. \& Gagkaeva, T.Yu. 2018. Analysis of contamination of annual and perennial Leguminosae grasses with fungi using quantitative PCR. Plant Protection News 2: 35-41. (in Russian). https://doi.org/10.31993/2308-6459-2018-2(96)-35-41 Osintseva, L.A. \& Chekryga, G.P. 2008. Fungi of melliferous bees pollenload. Mikologia fitopathologia 42: 464-469.

Pavón, M.Á., González, I., Martín, R. \& García Lacarra, T. 2012. ITS-based detection and quantification of Alternaria spp. in raw and processed vegetables by real-time quantitative PCR. Food Microbiology 32: 165-171. https://doi.org/10.1016/j.fm.2012.05.006 


\section{AGRICULTURAL AND FOOD SCIENCE}

A.S. Orina et al. (2020) 29: 265-275

Saharan, M.S. \& Saharan, G.S. 2004. Influence of weather factors on the incidence of Alternaria blight of cluster bean (Cyamopsis tetragonoloba (L.) Taub.) on varieties with different susceptibilities. Crop Protection 23: 1223-1227. https://doi.org/10.1016/j.cropro.2004.05.006

Schmidt-Heydt, M., Abdel-Hadi, A., Magan, N. \& Geisen, R. 2009. Complex regulation of the aflatoxin biosynthesis gene cluster of Aspergillus flavus in relation to various combinations of water activity and temperature. International Journal of Food Microbiology 135: 231-237. https://doi.org/10.1016/j.ijfoodmicro.2009.07.026

Schmidt-Heydt, M., Parra, R., Geisen, R. \& Magan, N. 2011. Modelling the relationship between environmental factors, transcriptional genes and deoxynivalenol mycotoxin production by strains of two Fusarium species. Journal of the Royal Society Interface 8:117-126. https://doi.org/10.1098/rsif.2010.0131

Skvorcov, V.Eh. 2004. Illustrated guide for botanical practices and excursions in Central Russia. Moscow, Russia: KMK. 506 p. (in Russian).

Tan, D.C., Flematti, G.R., Ghisalberti, E.L., Sivasithamparam, K., Chakraborty, S., Obanor, F. \& Barbetti, M.J. 2011. Mycotoxins produced by Fusarium species associated with annual legume pastures and sheep feed refusal disorders in Western Australia. Mycotoxin Research 27: 123-135. https://doi.org/10.1007/s12550-010-0085-0

Tivoli, B., Beasse, C., Lemarchand, E. \& Masson, E. 1996. Effect of ascochyta blight (Mycosphaerella pinodes) on yield components of single pea (Pisum sativum L.) plants under field conditions. Annals of Applied Biology 129: 207-216. https://doi.org/10.1111/j.1744-7348.1996.tb05745.x

Vleugels, T., Cnops, G., \& Van Bockstaele, E. 2013. Screening for resistance to clover rot (Sclerotinia spp.) among a diverse collection of red clover populations (Trifolium pratense L.). Euphytica 194: 371-382. https://doi.org/10.1007/s10681-013-0949-4

Yli-Mattila, T., Paavanen-Huhtala, S., Jestoi, M., Parikka, P., Hietaniemi, V., Gagkaeva, T., Sarlin, T., Haikara, A., Laaksonen, S. \& Rizzo, A. 2008. Real-time PCR detection and quantification of Fusarium poae, F. graminearum, F. sporotrichioides and $F$. langsethiae in cereal grains in Finland and Russia. Archives of Phytopathology and Plant Protection 41: 243-260. https://doi.org/10.1080/03235400600680659

Zaccardelli, M., Balmas, V., Altomare, C., Corazza, L. \& Scotti, C. 2006. Characterization of italian isolates of Fusarium semitectum from alfalfa (Medicago sativa L.) by AFLP analysis, morphology, pathogenicity and toxin production. Journal of Phytopathology 154: 454-460. https://doi.org/10.1111/j.1439-0434.2006.01128.x

Żelechowski, M., Olszewski, J. \& Kulik, T. 2019. A preliminary survey of cultured Fusaria from symptomatic legume grains in NorthEastern Poland. Toxins 11:569. https://doi.org/10.3390/toxins11100569

Zeng, Q.Y., Westermark, S.O., Rasmuson-Lestander, A. \& Wang, X.R. 2006. Detection and quantification of Cladosporium in aerosols by real-time PCR. Journal of Environmental Monitoring 8: 153-160. https://doi.org/10.1039/B509515H

Zitnick-Anderson, K., Simons, K. \& Pasche, J.S. 2018. Detection and qPCR quantification of seven Fusarium species associated with the root rot complex in field pea. Canadian Journal of Plant Pathology 40: 261-271. https://doi.org/10.1080/07060661.2018.1429494

Żukiewicz-Sobczak, W.A. 2013. The role of fungi in allergic diseases. Advances in Dermatology and Allergology 30: 42-45. https://doi.org/10.5114/pdia.2013.33377 